\title{
Harmfulness of xylophagous insects for silver birch (Betula pendula Roth.) in the left-bank forest-steppe of Ukraine
}

\author{
Yuriy Skrylnik ${ }^{1}$, Yana Koshelyaeva², Valentyna Meshkova ${ }^{1} \bowtie$ \\ ${ }^{1}$ Ukrainian Research Institute of Forestry and Forest Melioration named after G.M. Vysotsky, Pushkinska 86, Kharkiv, \\ 61024, Ukraine, phone: +38 0973719458, e-mail: valentynameshkova@gmail.com \\ ${ }^{2}$ Kharkiv National Agrarian University named after V.V. Dokuchaev, 62483, Kharkiv region, Kharkiv district, \\ Dokuchaevske - 2, Ukraine
}

\begin{abstract}
The aim of the research was to determine the rate of the damage of xylophagous insects for silver birch (Betula pendula Roth.) stands in the Left Bank Forest-steppe of Ukraine. Evaluation of physiological harmfulness considered a health condition of inhabited trees, features of maturating feeding and pathogens vectoring for the cases of so-called 'provoked aggressiveness' and its absence. Evaluation of technical harmfulness considered a location and depth of larval galleries and pupal chambers, colonized sapwood surface, and stem part. Evaluation of general harmfulness considered physiological harmfulness, technical harmfulness and generation number.

Among 22 xylophagous insect species, 4 species were widespread (Agrilus viridis (Linnaeus, 1758), Xylotrechus rusticus (Linnaeus, 1758), Xyleborinus saxeseni (Ratzeburg, 1837), and Xyleborinus attenuatus (Blandford, 1894)); 3 species were common, 6 species were rare and 9 species were single.

The highest physiological harmfulness is expected for Tremex fuscicornis (Fabricius, 1787) and Tremex magus (Fabricius, 1787), Chrysobothris affinis (Fabricius, 1774), Agrilus viridis (Linnaeus, 1758), Xylotrechus rusticus, and bark beetles. The highest technical harmfulness is expected for wood wasps - Tremex spp., jewel beetles Dicerca furcata (Thunberg, 1787) and Dicerca alni (Fischer von Waldheim, 1824), longhorn beetle Xylotrechus rusticus, and xylomycetophages - Xyleborinus sp.

All widespread species are evaluated by a wide range of physiological harmfulness. Three of them (all except Agrilus viridis) are evaluated by highly technical harmfulness and from moderate to highly general harmfulness. Among the species having a common occurrence, Tremex fuscicornis can be highly harmful only in the case of tree weakening by negative factors, another two species can be non-harmful, and Xiphydria longicollis (Geoffroy, 1785) can be low harmful in the case of tree weakening by negative factors. Among the rare species, Scolytus ratzeburgi Janson, 1856 can be low or moderately harmful and Tremex magus can be low or highly harmful depending on the presence or absence of other negative factors. Among single species, Zeuzera pyrina (Linnaeus, 1761) can be moderately harmful because it colonizes almost healthy trees. The rest three species can be moderately harmful in the case of tree weakening by negative factors.
\end{abstract}




\section{KeY WORDS}

maturation feeding, occurrence, pathogen vectoring, physiological activity, provoked aggressiveness, timber destruction

\section{INTRODUCTION}

Silver birch (Betula pendula Roth.) is a widespread tree in the forest and ornamental stands of Europe. However, its health condition deteriorates in different regions (Neuvonen et al. 2005; Goychuk et al. 2018; Meshkova et al. 2018) due to climate change (Heimonen et al. 2015) and anthropogenic influence (Raffa et al. 2008).

Xylophagous insects are an important factor of silver birch weakening and timber quality decrease and are so-called stem pests (Mozolevskaya 1974; Lieutier et al. 2004). Their harmfulness growth due to tree damage during maturation feeding and pathogens vectoring (Krokene and Solheim 1998; Alamouti et al. 2007; Linnakoski et al. 2008; Six 2012; Davydenko et al. 2014, 2017).

However, their development in deadwood is useful for the environment, because it provides timber destruction and habitats for many organisms (Wermellinger et al. 2007).

Xylophagous insects are mainly represented by three families of Coleoptera (Cerambycidae, Buprestidae and Curculionidae) and one family of Hymenoptera (Siricidae). They feed under the bark or in the sapwood for the most part of their life cycle (Lieutier et al. 2004). Outbreaks of xylophagous pests are most often associated with climatic conditions and anthropogenic pressure, particularly with forest management, which increases tree susceptibility to insect attacks (Klapwijk et al. 2016).

In 2014-2018, 22 species of xylophagous insects were identified in the stands of Betula pendula in the Left-bank forest-steppe of Ukraine (Skrylnik and Koshelyaeva 2015; Meshkova et al. 2018). The vast majority of these insects inhabits drying-up or felled trees, as well as coarse woody debris. However, some species are able to inhabit trees, which are suddenly weakened by different abiotic, biotic or anthropogenic causes (Ball and Simmons 1986; Lieutier et al. 2004; Hedgren 2010).

The most of xylophagous insects in silver birch are polyphagous; therefore, the data on their biological pe- culiarities are often not studied only on this tree species. For example, Xiphydria wood wasps colonize alder, birch, oak and willow (Pažoutová and Šrůtka 2007; Pažoutová et al. 2010). Xyleborinus saxesenii colonizes ash, birch, poplar, oak, elm and even on pine and fir (Fraedrich et al. 2011; Saruhan and Akyol 2012; Gomez et al. 2013; Saruhan 2013; Sarikaya 2015). However, the harmfulness of these insects was not quantified yet.

Approach to an evaluation of xylophagous insects' harmfulness was developed by E.G. Mozolevskaya (Mozolevskaya 1974) and takes into account the physiological and technical harmfulness. Rating of different features of tree colonization and life cycle of xylophagous insects also considered timber value of the damaged trees, particularly in different stem parts. Such an approach was applied for Scotch pine (Pinus sylvestris L.) pests in the European part of Russia (Mozolevskaya 1974), for Norway spruce (Picea abies (L.) H. Karst) pests in Belorussia (Kukhta et al. 2014), and for English oak (Quercus robur L.) (Meshkova and Kukina 2011) and Scots pine pests (Skrylnyk 2013, 2015) in Ukraine. It was shown (Meshkova 2017) that the estimated general harmfulness of certain insect species characterizes their potential harmfulness, while the actual harmfulness depends on region, tree health condition and insect occurrence.

The aim of this research was to determine the rate of the damage of xylophagous insects for silver birch (Betula pendula Roth.) stands in the Left Bank Foreststeppe of Ukraine.

\section{Material AND Methods}

Research was carried out in 2010-2018 in the Silver birch stands in Poltava (Myrgorodske Forest Enterprise), Sumy (Trostyanetske Forest Enterprise) and Kharkiv region (Zmiyivske, Chuguevo-Babchanske, Gutyanske and Skrypayivske Forest Enterprises, Kharkivska Forest Research Station of Ukrainian Research Institute of Forestry and Forest Melioration named after G.M. Vy- 
sotsky, National Nature Park 'Slobozhanskyi', Dendropark of Kharkiv National Agrarian University named after V.V. Dokuchaev, Park «Molodizhny») (Tab. 1).

Forest stands with birch from one to 80 -year-old as well as clear-cuts and the plots of thinning or selective sanitation felling were inspected, total 5357 trees in 18 localities (see Tab. 1).

Health condition of inspected trees was evaluated according to 'Sanitary rules in the forests of Ukraine' (Anonymous 1995). Each tree was classified into 1 of 6 categories of health condition (1st - healthy; 2nd - weakened; 3rd - severely weakened; 4th - drying-up; 5 th - recently died; 6th - died over a year ago). Frequency of occurrence of each xylophagous insect species was calculated as the proportion of infested trees from the total tree number of respective category of health condition.

The sections of $50 \mathrm{~cm}$ length were cut from stems and branches of the trees of different health condition, particularly with thick, transitional and thin bark. Some sections were left in the forest and others were brought to the laboratory and keeping in insectarium with in- serted nets or ventilation holes respectively. After adult emerging, all insects were identified. Then the sections were debarked, and galleries were examined to evaluate the parameters that are necessary for damage rating.

General harmfulness of each xylophagous species was evaluated according to the approach developed by E.G. Mozolevskaya (Mozolevskaya 1974). According to this, the general damage score of harm of each species was calculated as the product of technical damage by the physiological damage and correction coefficient, which reflects the number of generations $(1-$ for one-generation per year, 2 - for two generations per year, and 0.5 for development during two, and more years).

The physiological damage of insects was calculated as the sum of scores for their physiological activity (ability to colonize trees of different health condition), ability to damage the birch trees during maturation feeding and ability to vector the pathogens.

Physiologically active insect species, which are capable to colonize the trees of the 1st-2nd categories of health condition (healthy and weakened trees) were es-

Table 1. List of inspected stands of Silver birch in the Left-bank Forest-steppe

\begin{tabular}{|c|c|c|c|c|}
\hline Region & $\begin{array}{c}\text { Forest Enterprise, } \\
\text { Park or another object }\end{array}$ & Forestry* & Latitude, $\mathrm{N}$ & Longitude, E \\
\hline \multirow{9}{*}{ Kharkiv } & Zmiyivske & Zadonetzke (293) & $49^{\circ} 40^{\prime} 28^{\prime \prime}$ & $36^{\circ} 20^{\prime} 51^{\prime \prime}$ \\
\hline & Chuguevo-Babchanske & Malynivske (57) & $49^{\circ} 47^{\prime} 46^{\prime \prime}$ & $36^{\circ} 35^{\prime} 25^{\prime \prime}$ \\
\hline & Gutyanske & Krasnokutske (76) & $50^{\circ} 07^{\prime} 59^{\prime \prime}$ & $35^{\circ} 20^{\prime} 57^{\prime \prime}$ \\
\hline & Skrypayivske & Skrypayivske (107) & $49^{\circ} 44^{\prime} 22^{\prime \prime}$ & $36^{\circ} 31^{\prime} 28^{\prime \prime}$ \\
\hline & Kharkiv FRS URIFFM & Pivdenne (209) & $50^{\circ} 08^{\prime} 26^{\prime \prime}$ & $36^{\circ} 16^{\prime} 45^{\prime \prime}$ \\
\hline & Kharkiv FRS URIFFM & Dergachivs`ke (969) & $50^{\circ} 06^{\prime} 28^{\prime \prime}$ & $36^{\circ} 07^{\prime} 15^{\prime \prime}$ \\
\hline & NNP "Slobozhanskyi" & $(66)$ & $50^{\circ} 07^{\prime} 45^{\prime \prime}$ & $35^{\circ} 20^{\prime} 45^{\prime \prime}$ \\
\hline & \multicolumn{2}{|c|}{ Dendropark of Kharkiv National Agrarian University named after V.V. Dokuchaev (447) } & $49^{\circ} 54^{\prime} 20^{\prime \prime}$ & $36^{\circ} 29^{\prime} 54^{\prime \prime}$ \\
\hline & Kharkiv & Park “Molodizhny” (23) & $49^{\circ} 58^{\prime} 50^{\prime \prime}$ & $36^{\circ} 15^{\prime} 16^{\prime \prime}$ \\
\hline \multirow{6}{*}{ Poltava } & Myrgorodske & Velykobogachanske (300) & $49^{\circ} 47^{\prime} 28^{\prime \prime}$ & $33^{\circ} 43^{\prime} 21^{\prime \prime}$ \\
\hline & Myrgorodske & Gogolivske (300) & $49^{\circ} 54^{\prime} 57^{\prime \prime}$ & $33^{\circ} 49^{\prime} 18^{\prime \prime}$ \\
\hline & Myrgorodske & Komyshnyanske (225) & $50^{\circ} 11^{\prime} 01^{\prime \prime}$ & $33^{\circ} 40^{\prime} 46^{\prime \prime}$ \\
\hline & Myrgorodske & Psilske (201) & $49^{\circ} 38^{\prime} 17^{\prime \prime}$ & $33^{\circ} 50^{\prime} 35^{\prime \prime}$ \\
\hline & Myrgorodske & Chapajevske (405) & $49^{\circ} 07^{\prime} 20^{\prime \prime}$ & $34^{\circ} 02^{\prime} 33^{\prime \prime}$ \\
\hline & Myrgorodske & Shishakske (354) & $49^{\circ} 52^{\prime} 40^{\prime \prime}$ & $34^{\circ} 01^{\prime} 35^{\prime \prime}$ \\
\hline \multirow{3}{*}{ Sumy } & Trostyanetske & Lytovske (240) & $50^{\circ} 22^{\prime} 50^{\prime \prime}$ & $34^{\circ} 55^{\prime} 28^{\prime \prime}$ \\
\hline & Trostyanetske & Makivske (995) & $50^{\circ} 31^{\prime} 19^{\prime \prime}$ & $34^{\circ} 56^{\prime} 02^{\prime \prime}$ \\
\hline & Trostyanetske & Neskuchanske (90) & $50^{\circ} 29^{\prime} 05^{\prime \prime}$ & $34^{\circ} 57^{\prime} 56^{\prime \prime}$ \\
\hline
\end{tabular}

Note:* number of trees in brackets. 
timated at 10 points. Insects capable of colonizing trees of the 3rd-4th categories of health condition, coarse woody debris, and timber, obtained 1 point. Insects, capable of colonizing only trees of the 5th-6th categories of health condition (deadwood), stumps and timber, obtained 0.1 points. The ability of insects to damage trees during maturation feeding was evaluated with 2 points (noticeable damage), 1 point (slight damage), or 0 points (maturation feeding is absent).

Insects that are capable to be a vector of the pathogens were evaluated as 3 points, to be a vector of the wood-destroying fungi as 2 points, to be a vector of the blue stain fungi as 1 point, and score 0 was given to insects that cannot be the vector of a pathogen. Since most insects do not have special organs for pathogens vectoring, but they are all potential carriers of pathogens in the body, then the score 0 was given to those species that colonize only dead trees or small branches. Score 1 was given to species, which colonize felled trees, infect them with blue stain fungi and reduce timber cost. Score 2 was given to species, which colonize weakened trees (and open access to infection).

The technical damage was evaluated as a product of points of an overall score of destruction, colonized area and damaged wood value (the last coefficient for birch is 1.3 , considering its price comparing to the other tree species).

The general wood destruction was assessed as the sum of points that evaluate the depth of gallery location (score 1.2 for the depth to $1 \mathrm{~cm}$, a score 1.7 for $1-4 \mathrm{~cm}$, a score 4.3 for more than $4 \mathrm{~cm}$ ), their diameter (score 0 up to $0.3 \mathrm{~cm}$, score 0.1 over $0.3 \mathrm{~cm}$ ) and colonized surface of the sapwood (score 0 up to $1 \mathrm{dm}^{2}$, score 0.1 for $1-2 \mathrm{dm}^{2}$, and score 0.2 for over $2 \mathrm{dm}^{2}$ ). Stem part score was evaluated according to the value of respective timber assortments: insects, colonizing the stem parts with thick, transitional and thin bark are evaluated by $1.5,1.3$ and 1 points.

General damage was calculated as the product of point assessment for physiological, technical harmfulness and coefficient reflecting the number of generations ( 1 - for one-year generation, 2 - for two generations per year and 0.5 - for two-year development).

By the general harmfulness score, all studied xylophagous insects were referred to four groups, namely, highly harmful (the general harmfulness is 80 and more points), moderately harmful (20-79 points), low harm- ful (10-19 points), and non-harmful (less than 10 points) (Mozolevskaya 1974).

However, aggression of some xylophagous insects may be provoked by sudden action of abiotic factors (natural disasters: snow break, ice break, windstorm, fire, drought, etc.), biotic factors (cyclic increase of population density), and anthropogenic factors (careless forest management, untimely removal of timber production from the forest, sudden lighting of forest wall after thinning or neighbouring clear-cuts, mechanical damage to living trees, etc.) (Lieutier et al. 2004; Raffa et al. 2008; Meshkova et al. 2018). Therefore, we evaluated the physiological activity of xylophagous insects in Silver birch, considering the cases of so-called 'provoked aggressiveness' and its absence.

Frequency of occurrence of xylophagous insect species was calculated as the proportion of the colonized trees of given health condition from all the trees of given health condition. Standard error was calculated using statistical software package PAST: Paleontological Statistics Software Package for Education and Data Analysis (Hammer et al. 2001).

\section{Results}

In silver birch trees, we have identified 22 xylophagous insect species of three orders (Tab. 2).

Order Hymenoptera included three species from two families - Xiphydriidae: Xiphydria longicollis (Geoffroy, 1785) and Siricidae: Tremex fuscicornis (Fabricius, 1787) and Tremex magus (Fabricius, 1787). Order Lepidoptera was represented by one species from Cossidae: Zeuzera pyrina (Linnaeus, 1761). Order Coleoptera included six species of Buprestidae: Dicerca furcata (Thunberg, 1787), Dicerca alni (Fischer von Waldheim, 1824), Agrilus angustulus (Illiger, 1803), Agrilus betuleti (Ratzeburg, 1837), Agrilus viridis (Linnaeus, 1758), Chrysobothris affinis (Fabricius, 1774); seven species of Cerambycidae: Xylotrechus rusticus (Linnaeus, 1758); Aegomorphus clavipes (Schrank, 1781); Exocentrus adspersus Mulsant 1846; Leiopus linnei Wallin, Nylander \& Kvamme, 2009; Mesosa curculionides (Linnaeus, 1758); Mesosa nebulosa (Fabricius, 1781); Saperda scalaris (Linnaeus, 1758), and five species of Curculionidae (Scolytinae): Scolytus ratzeburgi Janson, 1856; Xyleborinus attenuatus (Bland- 
Table 2. Frequency of occurrence of xylophagous insects in Silver birch trees of different health condition in the Left-bank Forest Steppe, \% $( \pm \mathrm{SE})$

\begin{tabular}{|c|c|c|c|c|c|}
\hline \multirow{2}{*}{ No } & \multirow{2}{*}{ Insect taxa } & \multicolumn{3}{|c|}{ Category of tree health condition* } & \multirow{2}{*}{$\begin{array}{l}\text { Occurrence } \\
\text { of species }\end{array}$} \\
\hline & & $1-2(4084)$ & $3-4(809)$ & $5-6(464)$ & \\
\hline \multicolumn{6}{|c|}{ Order Hymenoptera } \\
\hline \multicolumn{6}{|c|}{ Family Xiphydriidae } \\
\hline 1 & Xiphydria longicollis (Geoffroy, 1785) & - & $1.70 \pm 0.454$ & - & common \\
\hline \multicolumn{6}{|c|}{ Family Siricidae } \\
\hline 2 & Tremex fuscicornis (Fabricius, 1787) & $0.60 \pm 0.121$ & $2.60 \pm 0.559$ & - & common \\
\hline 3 & Tremex magus (Fabricius, 1787) & $0.20 \pm 0.070$ & $0.37 \pm 0.213$ & - & rare \\
\hline \multicolumn{6}{|c|}{ Order Lepidoptera } \\
\hline \multicolumn{6}{|c|}{ Family Cossidae } \\
\hline 4 & Zeuzera pyrina (Linnaeus, 1761) & $0.05 \pm 0.035$ & - & - & single \\
\hline \multicolumn{6}{|c|}{ Order Coleoptera } \\
\hline \multicolumn{6}{|c|}{ Family Buprestidae } \\
\hline 5 & Dicerca furcata (Thunberg, 1787) & - & $0.49 \pm 0.246$ & - & rare \\
\hline 6 & Dicerca alni (Fischer von Waldheim, 1824) & - & $0.12 \pm 0.122$ & $0.43 \pm 0.304$ & single \\
\hline 7 & Agrilus angustulus (Illiger, 1803) & - & $1.20 \pm 0.383$ & $2.80 \pm 0.766$ & common \\
\hline 8 & Agrilus betuleti (Ratzeburg, 1837) & - & $0.49 \pm 0.246$ & $0.43 \pm 0.304$ & rare \\
\hline 9 & Agrilus viridis (Linnaeus, 1758) & $0.47 \pm 0.106$ & $17.68 \pm 1.341$ & - & widespread \\
\hline 10 & Chrysobothris affinis (Fabricius, 1774) & $0.02 \pm 0.022$ & $0.12 \pm 0.122$ & - & single \\
\hline \multicolumn{6}{|c|}{ Family Cerambycidae } \\
\hline 11 & Xylotrechus rusticus (Linnaeus, 1758) & $0.39 \pm 0.098$ & $16.93 \pm 1.319$ & - & widespread \\
\hline 12 & Aegomorphus clavipes (Schrank, 1781) & - & - & $0.22 \pm 0.218$ & single \\
\hline 13 & Exocentrus adspersus Mulsant 1846 & - & - & $0.22 \pm 0.218$ & single \\
\hline 14 & $\begin{array}{l}\text { Leiopus linnei Wallin, Nylander \& Kvamme, } \\
2009\end{array}$ & - & - & $0.22 \pm 0.218$ & single \\
\hline 15 & Mesosa curculionides (Linnaeus, 1758) & - & $0.37 \pm 0.213$ & $0.43 \pm 0.304$ & rare \\
\hline 16 & Mesosa nebulosa (Fabricius, 1781) & - & $0.12 \pm 0.122$ & $0.43 \pm 0.304$ & single \\
\hline 17 & Saperda scalaris (Linnaeus, 1758) & - & $0.37 \pm 0.213$ & $0.43 \pm 0.304$ & rare \\
\hline \multicolumn{6}{|c|}{ Family Curculionidae (Scolytinae) } \\
\hline 18 & Scolytus ratzeburgi Janson, 1856 & $0.29 \pm 0.084$ & $0.49 \pm 0.246$ & - & rare \\
\hline 19 & Xyleborinus attenuatus (Blandford, 1894) & $0.20 \pm 0.069$ & $12.11 \pm 1.147$ & - & widespread \\
\hline 20 & Xyleborinus saxeseni (Ratzeburg, 1837) & $0.49 \pm 0.109$ & $21.14 \pm 1.435$ & - & widespread \\
\hline 21 & Anisandrus maiche Stark, 1936 & $0.02 \pm 0.022$ & $0.12 \pm 0.122$ & - & single \\
\hline 22 & Trypodendron signatum (Fabricius, 1792) & $0.02 \pm 0.022$ & $0.12 \pm 0.122$ & - & single \\
\hline
\end{tabular}

Notes: * - number of inspected trees in brackets; “_“- a species was not found.

ford, 1894); Xyleborinus saxeseni (Ratzeburg, 1837); Anisandrus maiche Stark, 1936; Trypodendron signatum (Fabricius, 1792).

Among the revealed insects, 4 species are widespread (Agrilus viridis, Xylotrechus rusticus, Xylebori- nus saxeseni, and Xyleborinus attenuatus); 3 species are common (Xiphydria longicollis, Tremex fuscicornis, and Agrilus angustulus), 6 species are rare (Tremex magus, Dicerca furcata, Agrilus betuleti, Mesosa curculionides, Saperda scalaris, and Scolytus ratzeburgi) and 9 species 
are met occasionally or single (Zeuzera pyrina, Dicerca alni, Chrysobothris affinis, Aegomorphus clavipes, Exocentrus adspersus, Leiopus linnei, Mesosa nebulosa, Trypodendron signatum and Anisandrus maiche) (see Tab. 2). Four species (Scolytus ratzeburgi, Dicerca furcata, Agrilus betuleti, and Tremex fuscicornis) are most often confined to Betula spp., and other species damage different deciduous trees (Fraedrich et al. 2011; Gómez et al. 2013; Saruhan 2013; Heimonen et al. 2015).

Evaluation of xylophagous insects' physiological activity shows, that they prefer to colonize dead trees or stumps (9 species), wood debris or recently felled trees, severely weakened and drying up trees (12 species). Only Zeuzera pyrina was able to attack healthy and weakened trees (the trees of the 1st and 2nd category of health condition) (Tab. 2).

Most of the detected xylophagous insects (17 species) colonize felled trees and coarse woody debris (stem segments), namely Xiphydria longicollis, Tremex fuscicornis, T. magus, Dicerca furcata, D. alni, Agrilus viridis, Chrysobothris affinis, Xylotrechus rusticus, Aegomorphus clavipes, Mesosa curculionides, Mesosa nebulosa, Saperda scalaris, Scolytus ratzeburgi, Trypodendron signatum, Xyleborinus saxeseni, Xyleborinus attenuatus, and Anisandrus maiche.

Small woody debris (treetops and twigs) are inhabited by jewel beetles (Agrilus sp.), longhorn beetles -Exocentrus adspersus, Leiopus linnei and sometimes Mesosa sp. The stumps of birch trees are colonized by Dicerca furcata, D. alni, Saperda scalaris and Aegomorphus clavipes.

Agrilus viridis locally attacks the trees without external signs of weakening. In cases of its low population density, the callus covers the wounds after beetle emergence, and the tree continues to live. At a high population density of the beetle, birch trees inevitably die.

Individual development of birch bark beetle (Scolytus ratzeburgi) and big birch tremex wasp (Tremex fuscicornis) always completes in the trees with rather humid sapwood.

So-called 'provoked aggressiveness' was proved for 10 xylophagous insect species, including 5 species bark and ambrosia beetles, 1 longhorn beetle (Xylotrechus rusticus), 2 jewel beetles (Agrilus viridis and $A$. betuleti), and 2 wood wasps (T. fuscicornis and T. magus), which sometimes colonized almost healthy trees (Tab. 3). Such species' physiological activity was evalu- ated with 1 point when they attacked the trees of the $3^{\text {rd }}$ and $4^{\text {th }}$ category of health condition, wood debris or recently felled trees, and it was evaluated with 10 points when they attacked the trees of the $1^{\text {st }}$ and $2^{\text {nd }}$ category of health condition.

Table 3. Score of physiological harmfulness of xylophagous insects in Silver birch trees in the Left-bank Forest Steppe, points

\begin{tabular}{|c|c|c|c|c|c|}
\hline No & Insect species & 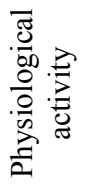 & 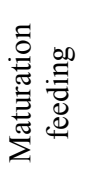 & 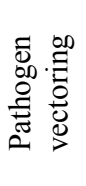 & 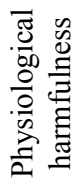 \\
\hline 1 & Xiphydria longicollis & 1 & 0 & 2 & 3 \\
\hline 2 & Tremex fuscicornis & $1 / 10$ & 0 & 2 & $3 / 12$ \\
\hline 3 & Tremex magus & $1 / 10$ & 0 & 2 & $3 / 12$ \\
\hline 4 & Zeuzera pyrina & 10 & 0 & - & 10 \\
\hline 5 & Dicerca furcata & 1 & 1 & - & 2 \\
\hline 6 & Dicerca alni & $0.1 / 1$ & 1 & - & $1.1 / 2$ \\
\hline 7 & Agrilus angustulus & $0.1 / 1$ & 1 & - & $1.1 / 2$ \\
\hline 8 & Agrilus betuleti & $0.1 / 1$ & 1 & $1 / 2$ & $2.1 / 4$ \\
\hline 9 & Agrilus viridis & $1 / 10$ & 2 & $1 / 2$ & $4 / 14$ \\
\hline 10 & Chrysobothris affinis & $1 / 10$ & 1 & 1 & $3 / 12$ \\
\hline 11 & Xylotrechus rusticus & $1 / 10$ & 2 & $1 / 2$ & $4 / 14$ \\
\hline 12 & Aegomorphus clavipes & 0.1 & 0 & - & 0.1 \\
\hline 13 & Exocentrus adspersus & 0.1 & 0 & - & 0.1 \\
\hline 14 & Leiopus linnei & 0.1 & 0 & - & 0.1 \\
\hline 15 & Mesosa curculionides & $0.1 / 1$ & 0 & - & $0.1 / 1$ \\
\hline 16 & Mesosa nebulosa & $0.1 / 1$ & 0 & - & $0.1 / 1$ \\
\hline 17 & Saperda scalaris & $0.1 / 1$ & 2 & - & $2.1 / 3$ \\
\hline 18 & Scolytus ratzeburgi & $1 / 10$ & 2 & 2 & $5 / 14$ \\
\hline 19 & Xyleborinus attenuatus & $1 / 10$ & 2 & 2 & $5 / 14$ \\
\hline 20 & Xyleborinus saxeseni & $1 / 10$ & 2 & 2 & $5 / 14$ \\
\hline 21 & Anisandrus maiche & $1 / 10$ & 2 & 2 & $5 / 14$ \\
\hline 22 & Trypodendron signatum & $1 / 10$ & 2 & 2 & $5 / 14$ \\
\hline
\end{tabular}

Notes: Minimal and maximal possible scores for each parameter are mentioned as numerator and denominator. Physiological activity - inhabiting of: 0.1 - dead trees or stumps; 1 - trees of the $3^{\text {rd }}$ and $4^{\text {th }}$ category of health condition, wood debris or recently felled trees; 10 - trees of the $1^{\text {st }}$ and $2^{\text {nd }}$ category of health condition. Maturation feeding: 0 - absent; 1 - slight damage; 2 - noticeable damage. Pathogen vectoring: 0 - absent; 1 - vectoring of blue stain fungi; 2 - vectoring of wood destroying fungi (Mozolevskaya 1974). Physiological harmfulness: total score considering minimal (numerator) or maximal (denominator) combination of scores for pathogen vectoring and physiological activity respectively. 
If Xiphydria longicollis, Dicerca alni, Agrilus angustulus, Agrilus betuleti, Mesosa curculionides, Mesosa nebulosi and Saperda scalaris colonize the trees of the $3^{\text {rd }}$ and $4^{\text {th }}$ category of health condition, wood debris or recently felled trees, their physiological activity was evaluated with 1 point, and in case of colonizing only dead trees or stumps, it was evaluated with 0.1 points.

Repeated attempts of healthy trees' attack by Tremex fuscicornis, Agrilus viridis, Xyleborinus sp., Anisandrus maiche, and Xylotrechus rusticus were revealed. The trees, weakened by these insects, inhabited by another bark and ambrosia beetles and wood wasps, and usually did not recover and die. The least aggressive species colonize trees that are weakened by more aggressive species, completing their development in the dead trees (Skrylnik and Koshelyaeva 2015).

Maturation feeding is absent for 8 analysed xylophagous insects. Five jewel beetles cause slight damage during maturation feeding by foliage. One jewel beetle (Agrilus viridis), one longhorn beetle (Saperda scalaris) and five bark beetles (Scolytus ratzeburgi, Xyleborinus attenuatus, Xyleborinus saxeseni, Anisandrus maiche, and Trypodendron signatum) cause noticeable damage (see Tab. 3).

Most xylophagous insects do not have special organs (mycangia) for vectoring pathogens, but they can passively transfer pathogens on their bodies (Krokene and Solheim 1998; Linnakoski et al. 2012; Six 2012). Physiologically active species during maturation feeding and when attempting to colonize living trees open the way to the blue-stain and wood-decay fungi, therefore, we estimate these species by score 1 or 2 respectively. Wood wasp oviposition in the surface layer of wood thus opening the way for a fungal infection. Bark beetles are known to bring the blue-stain fungi (Ophiostoma sp. and others) into their galleries. Xyleborinus attenuates, Xyleborinus saxeseni, Anisandrus maiche, and Trypodendron signatum bring mycelium of symbiotic fungi into the galleries to feed their larvae. These fungi are usually not pathogenic for trees, but they use some substances from xylem, which increase the negative influence of tree colonization. Together with symbiotic fungi, any other fungi can penetrate into xylem with these beetles (Six 2012).

Physiological harmfulness of xylophagous insects in birch trees was evaluated considering minimal (numerator) or maximal (denominator) combination of scores for pathogen vectoring and physiological activity respectively (see Tab. 3). Rather a high diapason of physiological harmfulness was evaluated for Tremex spp. and Chrysobothris affinis (3 to 12 points), Agrilus viridis and Xylotrechus rusticus (4 to 13 points) and bark beetles ( 5 to 14 points).

Evaluation of technical harmfulness of xylophagous insects shows that the larvae of some species (Xiphydria longicollis, Tremex fuscicornis, Tremex magus, Zeuzera pyrina, Dicerca furcata, Dicerca alni, and Xylotrechus rusticus) penetrate the sapwood and heartwood and even get to the opposite side of the stem. For these species, we mention the location of galleries as 'whole space' (Tab. 4, 5).

The larvae of xylomycetophages (Xyleborinus saxeseni, Xyleborinus attenuatus etc.) are gathered in groups of up to 50 specimens; therefore, their mutual galleries reach a width of about $10 \mathrm{~mm}$ at pupation time (see Tab. 4).

The analysis shows that the highest wood destruction is mainly caused by the larvae of wood wasps, a longhorn beetle Xylotrechus rusticus, xylomycetophages Xyleborinus sp., two jewel beetles species - Dicerca sp., and a leopard moth - Zeuzera pyrina (Tab. 6).

The larvae of the rest species of xylophagous insects (Agrilus angustulus, Agrilus betuleti, Dicerca furcata, Dicerca alni, Agrilus viridis, Chrysobothris affinis, Aegomorphus clavipes, Exocentrus adspersus, Leiopus linnei, Mesosa curculionides, Mesosa nebulosa, Saperda scalaris and Scolytus ratzeburgi) develop under the bark in phloem and do not cause technical injury. At the same time, if the tree is colonized by these insects, timber quality can decline due to the penetration of blue-stain and wood decay fungi.

The calculation score of the technical injuriousness for xylophagous insects indicates that in the case of a long time from birch tree death or felling to its processing, the highest technical injury to timber can be caused by wood wasps (Tremex sp.), jewel beetles Dicerca sp., longhorn beetle Xylotrechus rusticus, and xylomycetophages - Xyleborinus sp. (Tab. 7). Their harm increases as compared to some other insects because they not only damage the deeper timber layers but also colonize the lowest part of the stem, which is the most valuable. Damage of large logs can be detected only after the appearance of exit holes on the surface. 
Table 4. Location and size of xylophagous insects' larval galleries in Silver birch trees

\begin{tabular}{|c|c|c|c|c|c|}
\hline \multirow[b]{2}{*}{ No } & \multirow[b]{2}{*}{ Insect species } & \multirow[b]{2}{*}{ Part of stem colonized } & \multicolumn{3}{|c|}{ Galleries location and size } \\
\hline & & & location & $\begin{array}{c}\text { gallery } \\
\text { diameter, } \\
\mathrm{mm}\end{array}$ & $\begin{array}{l}\text { depth of gal- } \\
\text { lery location, } \\
\mathrm{mm}\end{array}$ \\
\hline \multicolumn{6}{|c|}{ Hymenoptera: Xiphydriidae } \\
\hline 1 & Xiphydria longicollis & Top, branches, thin bark & Sapwood & 4 & Whole space \\
\hline \multicolumn{6}{|c|}{ Hymenoptera: Siricidae } \\
\hline 2 & Tremex fuscicornis & Transitional, rough bark & Sapwood & 6 & Whole space \\
\hline 3 & Tremex magus & Transitional, rough bark & Sapwood & 6 & Whole space \\
\hline \multicolumn{6}{|c|}{ Lepidoptera: Cossidae } \\
\hline 4 & Zeuzera pyrina & Thin, transitional bark & Sapwood & 9 & $40-50$ \\
\hline \multicolumn{6}{|c|}{ Coleoptera: Buprestidae } \\
\hline 5 & Dicerca furcata & Thin, transitional, rough bark & Sapwood & 9 & Whole space \\
\hline 6 & Dicerca alni & Thin, transitional, rough bark & Sapwood & 9 & Whole space \\
\hline 7 & Agrilus angustulus & Twigs, branches & Phloem, bark & 2 & 1 \\
\hline 8 & Agrilus betuleti & Twigs, branches & Phloem, bark & 2 & 1 \\
\hline 9 & Agrilus viridis & Thin, transitional bark, twigs, branches & Phloem, bark & 3 & 2 \\
\hline 10 & Chrysobothris affinis & Thin, transitional bark, twigs, branches & Phloem, sapwood & 8 & 4 \\
\hline \multicolumn{6}{|c|}{ Coleoptera: Cerambycidae } \\
\hline 11 & Xylotrechus rusticus & Transitional, rough bark & Sapwood & 12 & Whole space \\
\hline 12 & Aegomorphus clavipes & Transitional bark & Phloem, sapwood & 10 & 5 \\
\hline 13 & Exocentrus adspersus & Twigs, branches, thin bark & Phloem, sapwood & 5 & 3 \\
\hline 14 & Leiopus linnei & Twigs, branches, thin bark & Phloem, sapwood & 5 & 3 \\
\hline 15 & Mesosa curculionides & Thin, transitional, rough bark & Phloem, sapwood & 12 & 5 \\
\hline 16 & Mesosa nebulosa & Thin, transitional, rough bark & Phloem, sapwood & 12 & 5 \\
\hline 17 & Saperda scalaris & Thin, transitional, rough bark & Sapwood & 9 & 3 \\
\hline \multicolumn{6}{|c|}{ Coleoptera: Curculionidae: Scolytinae } \\
\hline 18 & Scolytus ratzeburgi & Thin, transitional, rough bark & Bark, phloem, sapwood & 3 & 5 \\
\hline 19 & Xyleborinus attenuatus & Thin, transitional, rough bark & Sapwood & 1 & $80-100$ \\
\hline 20 & Xyleborinus saxeseni & Thin, transitional, rough bark & Sapwood & 1 & $60-80$ \\
\hline 21 & Anisandrus maiche & Twigs, branches, thin bark & Sapwood & 1 & $15-30$ \\
\hline 22 & Trypodendron signatum & Thin, transitional, rough bark & Sapwood & 2 & $30-40$ \\
\hline
\end{tabular}

Therefore, sometimes, inhabited logs are used in the construction of houses, which are then destroyed.

Evaluation of general harmfulness of xylophagous pests show that most of the analysed insects (16 species) in birch trees have a one-year generation in the Leftbank Forest-steppe of Ukraine (Tab. 8).

General harmfulness is the product of scores of physiological harmfulness, technical harmfulness and index of amount of generations. Physiological harm- fulness is taken from Table 2. Technical harmfulness is taken from Table 6. Index of generations number: 1 - 1 generation per year; 0.5 - development during two years. General harmfulness: considering minimal (numerator) or maximal (denominator) combination of scores for physiological harmfulness and index of generations amount respectively

Development of some stem pests' larvae accelerates at a higher temperature and slows at a low relative 
Table 5. Location and size of xylophagous insects' pupal chambers in Silver birch trees

\begin{tabular}{|c|c|c|c|c|c|}
\hline \multirow{2}{*}{ No } & \multirow{2}{*}{ Insect species } & \multicolumn{4}{|c|}{ Pupal chamber location and size } \\
\hline & & location & length, $\mathrm{mm}$ & width, $\mathrm{mm}$ & depth of location, $\mathrm{mm}$ \\
\hline \multicolumn{6}{|c|}{ Hymenoptera: Xiphydriidae } \\
\hline 1 & Xiphydria longicollis & Sapwood & 20 & 4 & Whole space \\
\hline \multicolumn{6}{|c|}{ Hymenoptera: Siricidae } \\
\hline 2 & Tremex fuscicornis & Sapwood & 35 & 6 & Whole space \\
\hline 3 & Tremex magus & Sapwood & 30 & 6 & Whole space \\
\hline \multicolumn{6}{|c|}{ Lepidoptera: Cossidae } \\
\hline 4 & Zeuzera pyrina & Sapwood & $50-60$ & 8 & $40-50$ \\
\hline \multicolumn{6}{|c|}{ Coleoptera: Buprestidae } \\
\hline 5 & Dicerca furcata & Sapwood & 18 & 6 & Whole space \\
\hline 6 & Dicerca alni & Sapwood & 20 & 6 & Whole space \\
\hline 7 & Agrilus angustulus & Upper sapwood layer, phloem & 8 & 1,5 & 3 \\
\hline 8 & Agrilus betuleti & Upper sapwood layer, phloem & 8 & 1,5 & 3 \\
\hline 9 & Agrilus viridis & Upper sapwood layer, phloem & 12 & 2 & 5 \\
\hline 10 & Chrysobothris affinis & Upper sapwood layer, phloem & 15 & 9 & 10 \\
\hline \multicolumn{6}{|c|}{ Coleoptera: Cerambycidae } \\
\hline 11 & Xylotrechus rusticus & Sapwood & 20 & 6 & Whole space \\
\hline 12 & Aegomorphus clavipes & Upper sapwood layer, phloem & 20 & 6 & 5 \\
\hline 13 & Exocentrus adspersus & Upper sapwood layer, phloem & 10 & 4 & 4 \\
\hline 14 & Leiopus linnei & Upper sapwood layer, phloem & 12 & 4 & 4 \\
\hline 15 & Mesosa curculionides & Upper sapwood layer, phloem & 20 & 6 & 5 \\
\hline 16 & Mesosa nebulosa & Upper sapwood layer, phloem & 20 & 6 & 5 \\
\hline 17 & Saperda scalaris & Upper sapwood layer, phloem & 24 & 7 & 5 \\
\hline \multicolumn{6}{|c|}{ Coleoptera: Curculionidae: Scolytinae } \\
\hline 18 & Scolytus ratzeburgi & Upper sapwood layer, phloem & 5 & 2 & 5 \\
\hline 19 & Xyleborinus attenuatus & Sapwood & 30 & 12 & 90 \\
\hline 20 & Xyleborinus saxeseni & Sapwood & 25 & 10 & 80 \\
\hline 21 & Anisandrus maiche & Sapwood & 12 & 2 & 30 \\
\hline 22 & Trypodendron signatum & Sapwood & 5 & 2 & $30-40$ \\
\hline
\end{tabular}

humidity of timber. Zeuzera pyrina, Dicerca furcata, and Dicerca alni usually develop for two years and an index of generations number for them is 0.5 points. The wood wasps have one- or two-year cycle of development depending on weather conditions and the rate of timber drying. Therefore, we assumed an index of generations number for Xiphydria longicollis, Tremex fuscicornis and Tremex magus as 0.5 and 1 (see Tab. 8).

According to our evaluation, the longhorn beetles Exocentrus adspersus, Leiopus linnei and Aegomorphus clavipes are the least harmful (with general harmfulness 0.17 and 0.23 points, other longhorn beetles (Mesosa curculionides, Mesosa nebulosa and Saperda scalaris) were characterized by $2.73-8.19$ points. The highest harmfulness is evaluated for longhorn beetle Xylotrechus rusticus (122.78 points), bark beetles Xyleborinus attenuatus and Xyleborinus saxeseni (120.12 points) and wood wasps Tremex fuscicornis and Tremex magus (105.24 points).

Certain xylophagous insects are prone to manifestation of aggression towards trees without visible signs of weakening in the cases when their aggressiveness 
Table 6. General score of Silver birch timber destruction by xylophagous insects in the Left-bank Forest Steppe, points

\begin{tabular}{|c|c|c|c|c|c|}
\hline No & Insect species & 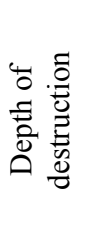 & 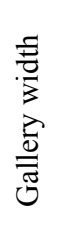 & 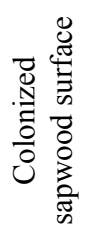 & 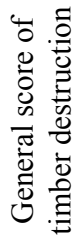 \\
\hline 1 & Xiphydria longicollis & 4.3 & 0.1 & 0.1 & 4.5 \\
\hline 2 & Tremex fuscicornis & 4.3 & 0.1 & 0.1 & 4.5 \\
\hline 3 & Tremex magus & 4.3 & 0.1 & 0.1 & 4.5 \\
\hline 4 & Zeuzera pyrina & 4.3 & 0.1 & 0.1 & 4.5 \\
\hline 5 & Dicerca furcata & 4.3 & 0.1 & 0.1 & 4.5 \\
\hline 6 & Dicerca alni & 4.3 & 0.1 & 0.1 & 4.5 \\
\hline 7 & Agrilus angustulus & 1.2 & 0 & 0 & 1.2 \\
\hline 8 & Agrilus betuleti & 1.2 & 0 & 0 & 1.2 \\
\hline 9 & Agrilus viridis & 1.2 & 0 & 0 & 1.2 \\
\hline 10 & Chrysobothris affinis & 1.2 & 0.1 & 0.1 & 1.4 \\
\hline 11 & Xylotrechus rusticus & 4.3 & 0.1 & 0.1 & 4.5 \\
\hline 12 & Aegomorphus clavipes & 1.2 & 0.1 & 0.1 & 1.4 \\
\hline 13 & Exocentrus adspersus & 1.2 & 0.1 & 0 & 1.3 \\
\hline 14 & Leiopus linnei & 1.2 & 0.1 & 0 & 1.3 \\
\hline 15 & Mesosa curculionides & 1.2 & 0.1 & 0.1 & 1.4 \\
\hline 16 & Mesosa nebulosa & 1.2 & 0.1 & 0.1 & 1.4 \\
\hline 17 & Saperda scalaris & 1.2 & 0.1 & 0.1 & 1.4 \\
\hline 18 & Scolytus ratzeburgi & 1.2 & 0.1 & 0.1 & 1.4 \\
\hline 19 & Xyleborinus attenuatus & 4.3 & 0.1 & 0 & 4.4 \\
\hline 20 & Xyleborinus saxeseni & 4.3 & 0.1 & 0 & 4.4 \\
\hline 21 & Anisandrus maiche & 1.7 & 0 & 0 & 1.7 \\
\hline 22 & Trypodendron signatum & 1.7 & 0 & 0 & 1.7 \\
\hline
\end{tabular}

Notes: General score of timber destruction is amount of points for depth of destruction, gallery width and colonized sapwood surface. Depth of destruction: score 1.2 - up to $1 \mathrm{~cm}$; score $1.7-1-4 \mathrm{~cm}$, score 4.3 - over $4 \mathrm{~cm}$. Gallery width: $0-$ up to $0.3 \mathrm{~cm} ; 0.1-$ over $0.3 \mathrm{~cm}$. Colonized sapwood surface: 0 - up to $1 \mathrm{dm}^{2} ; 0.1-1-2 \mathrm{dm}^{2} ; 0.2$ - over $2 \mathrm{dm}^{2}$ (Mozolevskaya 1974).

was provoked due to the action of abiotic, biotic or anthropogenic factors; therefore, it was advisable to evaluate the maximum possible harm.

By general harmfulness, all the analysed xylophagous insects were referred into four groups: I - highly harmful (the general harmfulness is 80 and more points), II - moderately harmful (20-79 points), III - low harmful (10-19 points), and IV - non-harmful (less than 10 points) (Tab. 8, Fig. 1).
Table 7. Score of technical harmfulness of xylophagous insects in Silver birch trees in the Left-bank Forest Steppe, points

\begin{tabular}{|c|c|c|c|c|c|}
\hline No & Insect species & 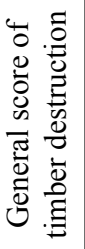 & 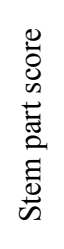 & 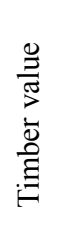 & 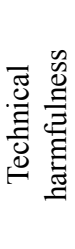 \\
\hline 1 & Xiphydria longicollis & 4.5 & 1.0 & 1.3 & 5.85 \\
\hline 2 & Tremex fuscicornis & 4.5 & 1.5 & 1.3 & 8.77 \\
\hline 3 & Tremex magus & 4.5 & 1.5 & 1.3 & 8.77 \\
\hline 4 & Zeuzera pyrina & 4.5 & 1.3 & 1.3 & 7.60 \\
\hline 5 & Dicerca furcata & 4.5 & 1.5 & 1.3 & 8.77 \\
\hline 6 & Dicerca alni & 4.5 & 1.5 & 1.3 & 8.77 \\
\hline 7 & Agrilus angustulus & 1.2 & 1.0 & 1.3 & 1.56 \\
\hline 8 & Agrilus betuleti & 1.2 & 1.0 & 1.3 & 1.56 \\
\hline 9 & Agrilus viridis & 1.2 & 1.3 & 1.3 & 2.02 \\
\hline 10 & Chrysobothris affinis & 1.4 & 1.3 & 1.3 & 2.36 \\
\hline 11 & Xylotrechus rusticus & 4.5 & 1.5 & 1.3 & 8.77 \\
\hline 12 & Aegomorphus clavipes & 1.4 & 1.3 & 1.3 & 2.36 \\
\hline 13 & Exocentrus adspersus & 1.3 & 1.0 & 1.3 & 1.69 \\
\hline 14 & Leiopus linnei & 1.3 & 1.0 & 1.3 & 1.69 \\
\hline 15 & Mesosa curculionides & 1.4 & 1.5 & 1.3 & 2.73 \\
\hline 16 & Mesosa nebulosa & 1.4 & 1.5 & 1.3 & 2.73 \\
\hline 17 & Saperda scalaris & 1.4 & 1.5 & 1.3 & 2.73 \\
\hline 18 & Scolytus ratzeburgi & 1.4 & 1.5 & 1.3 & 2.73 \\
\hline 19 & Xyleborinus attenuatus & 4.4 & 1.5 & 1.3 & 8.58 \\
\hline 20 & Xyleborinus saxeseni & 4.4 & 1.5 & 1.3 & 8.58 \\
\hline 21 & Anisandrus maiche & 1.7 & 1.0 & 1.3 & 2.21 \\
\hline 22 & Trypodendron signatum & 1.7 & 1.5 & 1.3 & 3.31 \\
\hline
\end{tabular}

Notes: Score of technical harmfulness of xylophagous insects is the product of general score of timber destruction, score of stem part and score of timber value. General score of timber destruction: is the last column of Table 5. Score of stem part: colonizing stem part with rough bark - 1.5 points; with transition bark -1.3 points; with thin bark -1 point. Timber value index for Silver birch is 1.3 (Mozolevskaya 1974).

In the case of tree weakening by negative factors, provoking aggressiveness of xylophagous insects, the group of highly harmful insects includes 5 species: Tremex fuscicornis, Tremex magus, Xylotrechus rusticus, Xyleborinus attenuatus, and Xyleborinus saxeseni. Moderately harmful are 6 species (Zeuzera pyrina, Agrilus viridis, Chrysobothris affinis, Scolytus ratzeburgi, Anisandrus maiche, Trypodendron signatum), 
Table 8. Score of general harmfulness of xylophagous insects in Silver birch trees in the Left-bank Forest Steppe, points

\begin{tabular}{|c|c|c|c|c|c|}
\hline No & Insect species & $\begin{array}{c}\text { Physiological } \\
\text { harmfulness }\end{array}$ & $\begin{array}{c}\text { Technical } \\
\text { harmfulness }\end{array}$ & $\begin{array}{c}\text { Index of generations } \\
\text { number }\end{array}$ & General harmfulness \\
\hline 1 & Xiphydria longicollis & 3 & 5.85 & $0.5 / 1$ & $8.77 / 17.55$ \\
\hline 2 & Tremex fuscicornis & $3 / 12$ & 8.77 & $0.5 / 1$ & $13.15 / 26.31 / 52.62 / 105.24$ \\
\hline 3 & Tremex magus & $3 / 12$ & 8.77 & $0.5 / 1$ & $13.15 / 26.31 / 52.62 / 105.24$ \\
\hline 4 & Zeuzera pyrina & 10 & 7.60 & 0.5 & 38.00 \\
\hline 5 & Dicerca furcata & 2 & 8.77 & 0.5 & 8.77 \\
\hline 6 & Dicerca alni & $1.1 / 2$ & 8.77 & 0.5 & $4.82 / 8.77$ \\
\hline 7 & Agrilus angustulus & $1.1 / 2$ & 1.56 & 1 & $1.71 / 3.12$ \\
\hline 8 & Agrilus betuleti & $2.1 / 3 / 3.1 / 4$ & 1.56 & 1 & $3.27 / 4.68 / 4.83 / 6.24$ \\
\hline 9 & Agrilus viridis & $4 / 5 / 13 / 14$ & 2.02 & 1 & $8.08 / 10.1 / 26.26 / 28.28$ \\
\hline 10 & Chrysobothris affinis & $3 / 12$ & 2.36 & 1 & $7.08 / 28.32$ \\
\hline 11 & Xylotrechus rusticus & $4 / 5 / 13 / 14$ & 8.77 & 1 & $35.08 / 43.85 / 114.01 / 122.78$ \\
\hline 12 & Aegomorphus clavipes & 0.1 & 2.36 & 1 & 0.23 \\
\hline 13 & Exocentrus adspersus & 0.1 & 1.69 & 1 & 0.17 \\
\hline 14 & Leiopus linnei & 0.1 & 1.69 & 1 & 0.17 \\
\hline 15 & Mesosa curculionides & $0.1 / 1$ & 2.73 & 1 & $0.27 / 2.73$ \\
\hline 16 & Mesosa nebulosa & $0.1 / 1$ & 2.73 & 1 & $0.27 / 2.73$ \\
\hline 17 & Saperda scalaris & $2.1 / 3$ & 2.73 & 1 & $5.73 / 8.19$ \\
\hline 18 & Scolytus ratzeburgi & $5 / 14$ & 2.73 & 1 & $13.65 / 38.22$ \\
\hline 19 & Xyleborinus attenuatus & $5 / 14$ & 8.58 & 1 & $42.9 / 120.12$ \\
\hline 20 & Xyleborinus saxeseni & $5 / 14$ & 8.58 & 1 & $42.9 / 120.12$ \\
\hline 21 & Anisandrus maiche & $5 / 14$ & 2.21 & 1 & $11.05 / 30.94$ \\
\hline 22 & Trypodendron signatum & $5 / 14$ & 3.31 & 1 & $16.55 / 46.34$ \\
\hline
\end{tabular}

Notes: Different possible scores for each parameter are mentioned as numerator and denominator.

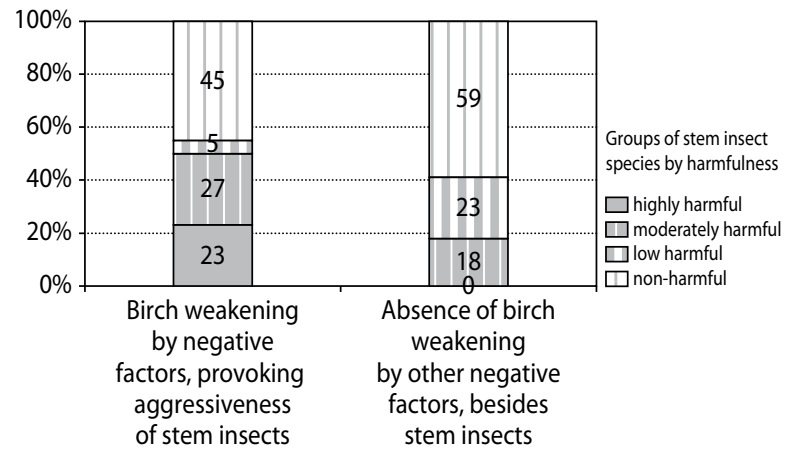

Figure 1. Distribution of silver birch xylophagous insects by harmfulness in the case of tree weakening by other negative factors, provoking aggressiveness of these insects, and in the absence of such impact (groups by harmfulness: I - highly harmful with general harmfulness $\geq 80$ points, II - moderately harmful - 20-79 points, III - low harmful - 10-19 points, and IV - non-harmful $-<10$ points) low harmful is 1 species - Xiphydria longicollis, and non-harmful are 10 species (Dicerca furcata, Dicerca alni, Agrilus angustulus, Agrilus betuleti, Aegomorphus clavipes, Exocentrus adspersus, Leiopus linnei, Mesosa curculionides, Mesosa nebulosa. and Saperda scalaris).

In the absence of tree weakening by other negative factors, provoking aggressiveness of xylophagous insects, these insects colonize severely weakened or recently died trees, and the score of their physiological, technical harmfulness is minimal. In such a case, there is no one species in the group of highly harmful xylophagous insects. A group of moderately harmful xylophagous insects includes 4 species (Xylotrechus rusticus, Xyleborinus attenuatus, Xyleborinus saxeseni and Zeuzera pyrina), and a group of low harmful xylophagous insects includes five species (Tremex fuscicornis, Tremex magus, Scolytus ratzeburgi, Anisan- 
drus maiche and Trypodendron signatum). The wood wasps Tremex fuscicornis and Tremex magus are not harmful in such a case, because they colonize heavily weakened trees and have a prolonged generation (two and more years). A group of non-harmful xylophagous insects includes 13 species (Xiphydria longicollis, Dicerca furcata, Dicerca alni, Chrysobothris affinis, Agrilus angustulus, Agrilus betuleti, Agrilus viridis, Aegomorphus clavipes, Exocentrus adspersus, Leiopus linnei, Mesosa curculionides, Mesosa nebulosa, and Saperda scalaris).

\section{Discussion}

Xylophagous insects can cause physiological and/or technical damage (Mozolevskaya 1974). Physiological damage reveals in tree weakening or killing. The ability to weaken and kill a tree is determined by an insect's ability to inhabit a viable tree (physiological activity), to weaken it by maturation feeding and/or by vectoring pathogens. In the case of sudden tree weakening, it can be inhabited by usually non-aggressive insect species, and in the case of passive transmission of pathogens, an insect can vector both blue-stain and wood-destroying fungi. In the case of high insect population density, tree damage by maturation feeding can be rather high. Therefore, a certain range of points is given for some of the analysed xylophagous insects, and it was the highest for wood wasps Tremex spp., jewel beetles Chrysobothris affinis and Agrilus viridis, longhorn beetle Xylotrechus rusticus, and ambrosia beetles (see Tab. 2).

The concept of technical harmfulness refers to the assessment of the reduction of the quality of only the wood that is used as a forest product. In such a case, technical damage reveals in a decrease of timber quality in the result of xylophagous insect development inside it. Such damage is greater for insects with the wider and deeper location of galleries and pupal chambers, with larger damaged stem surface and location of galleries in the most valuable (lower) part of the stem (see Tab. 3-5).

Insect species inhabiting wood that is not intended for use are not harmful (Skrylnik 2013, 2015; Meshkova 2017). They are, on the contrary, useful in the ecosystem because of contribution to formation of habitats for many organisms. The highest technical harmfulness among the analysed xylophagous insects was evaluated for wood wasps (Tremex sp.), jewel beetles Dicerca sp., longhorn beetle Xylotrechus rusticus and ambrosia beetles - Xyleborinus sp. (see Tab. 6).

As an evaluation of general harmfulness of xylophagous insects considers an index of generations number (Mozolevskaya 1974), therefore, the same insect may be more harmful in the warm year with greater generation number and less harmful in dry timber, where larval development slows down (Skrylnik 2015).

All the mentioned features were examined for each of the revealed xylophagous insects and evaluated mainly using scores, suggested by E.G. Mozolevskaya (Mozolevskaya 1974). At the same time, two additional aspects were considered.

The first aspect suggests that the same insect may usually inhabit severely weakened or dying trees, logs or woody debris, but after fire, flood, drought, defoliation by foliage browsing insects or sudden decrease of stand density the trees become susceptible to attacks of wider scope of xylophagous insects (Lieutier et al. 2004; Raffa et al. 2008). So, the harmfulness of xylophagous insects was evaluated for the case of tree weakening by other negative factors, provoking aggressiveness of xylophagous insects, and in the absence of such an impact (see Fig. 1).

The second aspect considers that the harmfulness of xylophagous insects depends on their population density or occurrence (Meshkova 2017). For example, Zeuzera pyrina attacks rather healthy trees and kills them, but it has a single occurrence. Agrilus viridis locally attacks the trees without external signs of weakening. In cases of low insect population density, the callus covers the wounds after adult emergence, and the tree continues to live. At high population density, birch trees inevitably die. Among the revealed xylophagous species, only 4 species are widespread (Agrilus viridis, Xylotrechus rusticus, Xyleborinus attenuates and Xyleborinus saxeseni) and 3 species are common (18\% and $14 \%$ respectively), whereas the rare and single insects make up 6 and 9 species (27 and 41\%). So, the widespread and common species can cause more harm than rare and single ones with the same features.

Four groups of xylophagous insects were determined by general harmfulness. In the absence of tree weakening by other negative factors, provoking aggressiveness of xylophagous insects, the score of their harmfulness is minimal, and highly harmful species are 
absent. Four species (18\%) are moderately harmful, five species (23\%) are low harmful and 13 species (59\%) are non-harmful. A group of moderately harmful xylophagous insects includes 4 species (Xylotrechus rusticus, Xyleborinus attenuatus, Xyleborinus saxeseni and Zeuzera pyrina).

In the case of tree weakening by other negative factors, provoking aggressiveness of xylophagous insects, the score of their harmfulness is maximal. There are 5 highly harmful species (23\%), 6 moderately harmful species, $1(5 \%)$ low harmful species and $10(45 \%)$ non-harmful species. A group of highly harmful stem insects includes 5 species: Tremex fuscicornis, Tremex magus, Xylotrechus rusticus, Xyleborinus attenuatus and Xyleborinus saxeseni. So, in all the cases, Xylotrechus rusticus, Xyleborinus attenuatus and Xyleborinus saxeseni are the most dangerous xylophagous pests of silver birch, both by their biological features and occurrence (see Tab. 2-6, Fig. 1).

\section{Conclusions}

In the silver birch (Betula pendula Roth.) stands of the left-bank forest-steppe of Ukraine, 22 xylophagous insect species are identified. Among them, 4 species are widespread (Agrilus viridis, Xylotrechus rusticus, Xyleborinus saxeseni and Xyleborinus attenuates); 3 species are common (Xiphydria longicollis, Tremex fuscicornis and Agrilus angustulus), 6 species are rare (Tremex magus, Dicerca furcata, Agrilus betuleti, Mesosa curculionides, Saperda scalaris and Scolytus ratzeburgi) and the rest species are single.

The highest diapason of physiological harmfulness is evaluated for Tremex spp., Chrysobothris affinis, Agrilus viridis. Xylotrechus rusticus and bark beetles. The highest technical harmfulness is evaluated for wood wasps (Tremex sp.), jewel beetles Dicerca sp., longhorn beetle Xylotrechus rusticus and xylomycetophages - Xyleborinus sp.

In the case of tree weakening by negative factors, provoking aggressiveness of stem insects, the group of highly harmful stem insects includes 5 species: Tremex fuscicornis, Tremex magus, Xylotrechus rusticus, Xyleborinus attenuatus and Xyleborinus saxeseni.

In the absence of tree weakening by other negative factors, provoking aggressiveness of stem insects, these insects colonize severely weakened or recently died trees, and the score of their physiological, technical harmfulness is minimal. In such a case, there is no one species in the group of highly harmful stem-insects. A group of moderately harmful stem insects includes 4 species (Xylotrechus rusticus, Xyleborinus attenuatus, Xyleborinus saxeseni and Zeuzera pyrina).

All the widespread species are evaluated by a wide range of physiological harmfulness, three of them (all except Agrilus viridis) are evaluated by highly technical harmfulness and from moderate to highly general harmfulness. Among species with the common occurrence, Tremex fuscicornis can be highly harmful only in the case of tree weakening by negative factors, another two species can be non-harmful, and Xiphydria longicollis can be low harmful in the case of tree weakening by negative factors. Among rare species, Scolytus ratzeburgi can be low or moderately harmful and Tremex magus can be low or highly harmful depending on the presence or absence of other negative factors. Among single species, Zeuzera pyrina can be moderately harmful, because it colonizes almost healthy trees. The rest three species can be moderately harmful in the case of tree weakening by negative factors.

\section{RefERenCES}

Alamouti, S.M., Kim, J.J., Humble, L.M., Uzunovic, A., Breuil, C. 2007. Ophiostomatoid fungi associated with the northern spruce engraver, Ips perturbatus, in western Canada. Antonie van Leeuwenhoek, 91 (1), 19-34. https://doi.org/10.1007/s10482-0069092-8

Anonimous. 1995. Sanitary rules in the forests of Ukraine (in Ukrainian). Derzhkomlisgosp Ukrayiny, Kiev.

Ball, J., Simmons, G. 1986. The influence of host condition on post first instar development of the bronze birch borer, Agrilus anxius (Coleoptera: Buprestidae). The Great Lakes Entomologist, 19 (2), 73-76.

Davydenko, K., Vasaitis, R., Menkis, A. 2017. Fungi associated with Ips acuminatus (Coleoptera: Curculionidae) in Ukraine with a special emphasis on pathogenicity of ophiostomatoid species. European Journal of Entomology, 114, 77-85. https://doi. org/10.14411/eje.2017.011 
Davydenko, K., Vasaitis, R., Meshkova, V., Menkis, A. 2014. Fungi associated with the red-haired bark beetle, Hylurgus ligniperda (Coleoptera: Curculionidae) in the forest-steppe zone in eastern Ukraine. European Journal of Entomology, 111 (4), 561-565. https://doi.org/10.14411/eje.2014.070

Fraedrich, S.W., et al. 2011. Susceptibility to laurel wilt and disease incidence in two rare plant species, pondberry and pondspice. Plant Disease, 95 (9), 1056-1062.

Gómez, D., Reyna, R., Pérez, C., Martínez, G. 2013. First record of Xyleborinus saxesenii (Ratzeburg) (Coleoptera: Curculionidae: Scolytinae) in Uruguay. The Coleopterists Bulletin, 67 (4), 536-538.

Goychuk, A., Drozda, V., Shvets, M. 2018. Risk of birch disappearance in Zhytomyr Polissya of Ukraine. Proceedings of the forestry academy of sciences of Ukraine, 17, 16-25. DOI: https://doi. org $/ 10.15421 / 411816$

Hammer, O., Harper, D.A. T., Ryan, P.D. 2001. PAST: paleontological statistics software package for education and data analysis. Palaeontologia Electronica, 4, 1-9.

Hedgren O. 2010. Some notes on the ecology of the Tremex wasp T. fuscicornis (Hymenoptera: Siricidae). Entomologisk Tidskrift, 131 (1), 1-4.

Heimonen, K., et al. 2015. Insect herbivore damage on latitudinally translocated silver birch (Betula pendula) - predicting the effects of climate change. Climatic Change, 131 (2), 245-257.

Klapwijk, M.J., Bylund, H., Schroeder, M., Björkman, C. 2016. Forest management and natural biocontrol of insect pests. Forestry, 89 (3), 253-262. DOI:10.1093/forestry/cpw019

Krokene, P., Solheim, H. 1998. Pathogenicity of four blue-stain fungi associated with aggressive and nonaggressive bark beetles. Phytopathology, 88 (1), 39-44. https://doi.org/10.1094/PHYTO.1998.88.1.39

Kukhta, V.N., Blintsov, A.I., Sazonov, A.A. 2014. Bark beetles of Norway spruce and measures on regulation of their population (in Russian). BGTU, Minsk.

Lieutier, F., Day, K.R., Battisti, A., Gregoire, J.C., Evans, H.F. 2004. Bark and wood boring insects in living trees in Europe: a synthesis. Kluwer Acad. Publishers, Dordrecht-Boston-London.

Linnakoski, R., et al. 2008. Fungi, including Ophiostoma karelicum sp. nov., associated with Scolytus ratzeburgi infesting birch in Finland and Russia. Mycological Research, 112 (12), 1475-1488. DOI: 10.1016/j.mycrez.2008.06.007

Meshkova, V.L. 2017. Evaluation of harm (injuriousness) of stem insects in pine forest. Scientific Bulletin of UNFU, 27 (8), 101-104. DOI: 10.15421/40270816

Meshkova V.L., Koshelyaeva Y.V., Skrylnik Y.Y., Zinchenko O.V. 2018. Symptoms and signs of Silver birch damage and injury in Dergachivske forestry (in Ukrainian). The Bulletin of Kharkiv National Agrarian University. Series Phytopathology and Entomology, 1/2, 101-110.

Meshkova, V.L., Kukina, O.N. 2011. Injuriousness of xylobionts in the oak clear-cuts in the Left-Bank Ukraine (in Russian). Proceedings of St. Petersburg Forestry Academy, 196, 238-245.

Mozolevskaya, E.G. 1974. Evaluation of stem pests injuriousness (in Russian). Science Papers of Moscow Forest and Technical Institute, 65, 124-132.

Neuvonen, S., Bylund, H., Tømmervik, H. 2005. Forest defoliation risks in birch forest by insects under different climate and land use scenarios in northern Europe. In: Plant ecology, herbivory, and human impact in Nordic mountain birch forests. Springer, Berlin, Heidelberg, 125-138.

Pažoutová, S., Šrůtka, P. 2007. Symbiotic relationship between Cerrena unicolor and the horntail Tremex fuscicornis recorded in the Czech Republic. Czech Mycology, 59 (1), 83-90.

Pažoutová, S., Šrůtka, P., Holuša, J., Chudíčková, M., Kolařík, M. 2010. Diversity of xylariaceous symbionts in Xiphydria woodwasps: role of vector and a host tree. Fungal Ecology, 3 (4), 392-401.

Raffa, K.F., et al. 2008. Cross-scale drivers of natural disturbances prone to anthropogenic amplification: The dynamics of bark beetle eruptions. Bioscience, 58, 501-517.

Rauleder, H. 2003. Observations on the flight dynamics of bark beetle (Xyleborus saxeseni and dispar). Gesunde Pflanzen, 55 (3), 53-61. https://doi. org/10.1046/j.1439-0345.2003.03001.x

Sarikaya, O. 2015. Observations on the beetles Anisandrus dispar (Fabricius, 1792) and Xyleborinus saxesenii (Ratzeburg, 1837) in Kaznak oak Forest Nature Protection Area in the South Western of Turkey. International Journal of Agriculture Innovations and Research, 4 (2), 357-360. 
Saruhan, I. 2013. Monitoring population density and fluctuations of Xyleborus dispar and Xyleborinus saxesenii (Coleoptera: Scolyt1dae) with red winged sticky traps in hazelnut orchards. African Journal of Agricultural Research, 8 (19), 2189-2194. DOI: 10.5897/AJAR11.1317

Saruhan, İ., Akyol, H. 2012. Monitoring population density and fluctuations of Anisandrus dispar and Xyleborinus saxesenii (Coleoptera: Scolytinae, Curculionidae) in hazelnut orchards. African Journal of Biotechnology, 11 (18), 4202-4207. DOI: 10.5897/AJB11.4185

Six, D.L. 2012. Ecological and evolutionary determinants of bark beetle-fungus symbioses. Insects, 3 (1), 339-366. DOI.org/10.3390/insects3010339

Skrylnik, Yu.Ye. 2013. Injuriousness of longhorn beetles (Coleoptera, Cerambycidae) in pine stands of the Left-bank Ukraine (in Ukrainian). The Bulletin of Kharkiv National Agrarian University, Series Entomology and Phytopathology, 10, 148-159.

Skrylnik, Yu.Ye. 2015. Injuriousness of stem insects in the pine stands of the Left-bank Forest-Steppe of Ukraine (in Ukrainian). PhD Thesis, Kharkiv.

Skrylnik, Yu.Ye., Koshelyaeva, Ya.V. 2015. First results of study the stem insects of silver birch (Betula pendula Roth.) in the Kharkiv Region (in Ukrainian). The Kharkov Entomological Society Gazette, 23 (1), 54-58.

Wermelinger, B., Fluckiger, P.F., Obrist, M.K., Duelli, P. 2007. Horizontal and vertical distribution of saproxylic beetles (Col., Buprestidae, Cerambycidae, Scolytinae) across sections of forest edges. Journal of Applied Entomology, 131 (2), 104-114. 